\title{
Expression of c-erbB-2, c-myc, and c-ras oncoproteins, insulin-like growth factor receptor I, and epidermal growth factor receptor in ovarian carcinoma
}

P A van Dam, I B Vergote, D G Lowe, J V Watson, P Van Damme, J-C Van der Auwera, J H Shepherd

\begin{abstract}
Aims-To assess whether the overexpression of five dominant oncogene encoded proteins is crucial to the pathogenesis of ovarian carcinoma and whether this provides any useful prognostic information. Methods-The expression of the insulinlike growth factor 1 receptor (ILGFR 1), epidermal growth factor receptor (EGFR), and the c-erbB-2, c-ras, and cmyc products was studied by multiparameter flow cytometry in 80 patients with epithelial ovarian cancer for whom long term follow up was available.
\end{abstract}

Results-Overexpression of ILGFR 1, EGFR, c-erbB-2, c-ras and c-myc was found in, respectively, nine of $80(11 \%)$, 10 of $80(12 \%), 19$ of $80(24 \%), 16$ of 80 $(20 \%)$ and 28 of $80(35 \%)$ ovarian carcinomas. The levels of expression of ILGFR 1, EGFR, c-erbB-2 and c-ras were significantly higher in the tumours of patients with recurrent or persistent disease after chemotherapy than in the tumours of patients at initial presentation $(p<0.02)$. Multivariate analysis showed that residual tumour ( $p<0.001)$, FIGO stage $(p=$ $0.002)$, EGFR overexpression $(p=0.030)$ and previous chemotherapy $(p=0.034)$ were independent variables for predicting survival.

Conclusions-Overexpression of these oncoproteins only occurs in a small proportion of ovarian carcinomas but may have an important role in the progression of the disease.

(F Clin Pathol 1994;47:914-919)

Recent insight into the molecular biology of cancer raises the hypothesis that carcinogenesis can be explained by a complex multistep process of activation of oncogenes and inactivation of tumour suppressor genes, these events acting synergistically to produce the malignant phenotype. ${ }^{1}$ Alterations in the expression of oncogenes and antioncogenes, caused by mutation, rearrangement or gene amplification, or altered gene transcription, can occur spontaneously or be induced by carcinogens. ${ }^{23}$ Although for some tumour types (such as colonic carcinoma) the cascade of tumourigenic events is on the verge of being revealed, the molecular biology of epithelial ovarian cancer remains an enigma. ${ }^{4}$
In this study the expression of five dominant oncogene-encoded proteins-insulin-like growth factor I receptor (ILGFR I), epidermal growth factor receptor (EGFR), and the $c$-erbB-2, c-ras and c-myc products-was measured by multiparameter flow cytometry in 80 patients with ovarian carcinoma. The investigation aimed to assess whether overexpression of these oncoproteins has a crucial role in the pathogenesis of the disease and whether it provides any useful prognostic information. Epidermal growth factor receptor, ILGFR I, and the $c$-erbB-2 gene product are transmembrane cell surface glycoproteins which have intrinsic tyrosine kinase activity. They function as signal receptors: ligand binding leads to pleotropic effects on cells, including stimulation of mitogenesis. ${ }^{256}$ The products of the c-ras gene family are involved with signal transmission in the cytoplasm: they seem to link the effects of growth factor stimulation of receptors with inositol phospholipid metabolism. ${ }^{7} \mathrm{C}-m y c$ is a nuclear oncoprotein involved in regulating cell proliferation and possibly in cell differentiation. ${ }^{8}$

\section{Methods}

Eighty patients with epithelial ovarian cancer were included in this study. Each patient had an exploratory laparotomy as part of treatment for epithelial ovarian carcinoma at the Norwegian Radium Hospital between 1982 and 1989. The stage of the disease was assigned according to the International Federation of Gynaecologists and Obstetricians' (FIGO) staging criteria. ${ }^{9}$ In 40 patients tumour was obtained at the initial operation before any adjuvant treatment was given. Of these 40 patients, five also had tumour samples frozen at second-look or subsequent laparotomy. All of the remaining 40 patients had persistent disease after chemotherapy; tumour samples were collected only at second-look or subsequent laparotomy.

Samples of normal ovary were collected during the study period from 30 age matched patients undergoing hysterectomy and salpingo-oophorectomy for benign uterine disease. Histological material from each case was reviewed by one pathologist. The histological type and grade were assigned with the use of World Health Organisation criteria. ${ }^{10}$ All of the patients with advanced disease in this study received platinum based chemotherapy. The patients' details are given 
Table 1 Clinical and histological characteristics of 80 patients with epithelial ovarian cancer

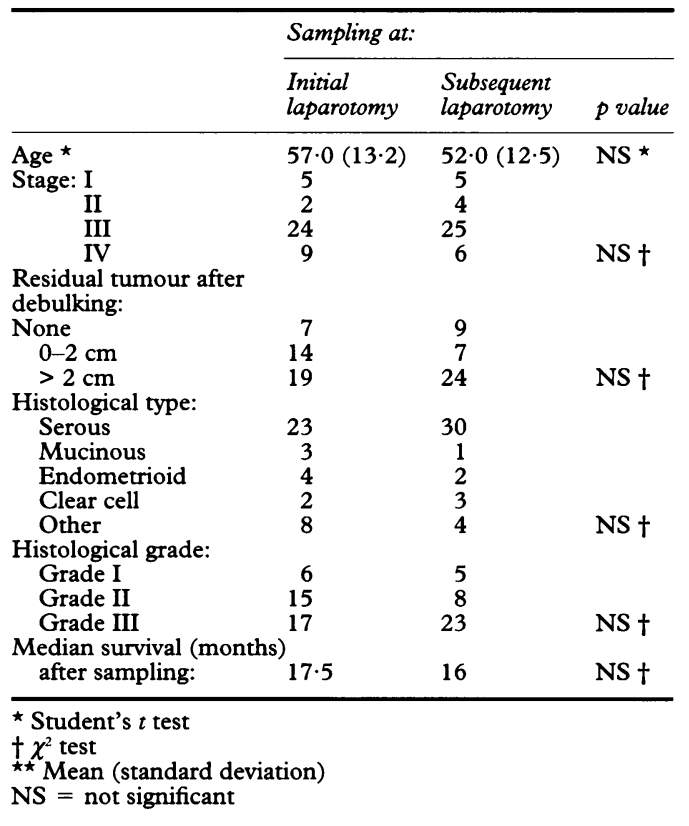

in table 1. The follow up of the patients was assessed in March 1991. No patients were lost to follow up.

Representative samples of the primary ovarian tumours were obtained from surgical specimens in the operating theatre. They were immediately dissected free from necrotic tissue and divided into two adjacent parts. The first block, of about $0.5 \mathrm{~cm}^{3}$, was snap frozen in liquid nitrogen and stored at $-70^{\circ} \mathrm{C} .{ }^{11}$ The second part was fixed in formalin and processed routinely for haematoxylin and eosin staining.

The monoclonal antibody NEU3 (provided as ascites) was used to label the internal domain of the human c-erbB-2 oncoprotein (Cambridge Research Biochemicals Ltd, Harston, England). ${ }^{12}$ The EGFR was probed with the well characterised R1 monoclonal antibody provided by Drs B Gullick and $M$ Waterfield (ICRF, Laboratories, London) (1982). ${ }^{13}$ The $6 \mathrm{E} 10$ monoclonal antibody (Cambridge Research Biochemicals, England) was used to label the $c$-myc gene product. ${ }^{14}$ The F132-G2 and $a$ R3 antibodies, recognising p21 pan-ras and ILGFR I receptor, respectively, were purchased from Oncogene Science (USA). All primary monoclonal antibodies were mouse IgG and were stained with fluorescein isothiocyanate

Table 2 Tumour DNA aneuploidy, S-phase fraction, and oncoprotein expression in normal and carcinomatous ovary

\begin{tabular}{|c|c|c|c|}
\hline & $\begin{array}{l}\text { Normal ovary } \\
n=30\end{array}$ & $\begin{array}{l}\text { Ovarian carcinoma } \\
n=80\end{array}$ & Significance \\
\hline $\begin{array}{l}\text { DNA aneuploidy } \\
\text { SPF† } \\
\text { EGFR+t } \\
\text { ILGFRI†t } \\
c \text {-erbB-2†t } \\
c \text {-rastt } \\
c-\text { myctt }\end{array}$ & $\begin{array}{l}0 \\
9 \cdot 4( \pm 3 \cdot 2) \\
3(0-36) \\
7(0-45) \\
8(0-35) \\
8(0-49) \\
16(0-30)\end{array}$ & $\begin{array}{l}47 \\
18 \cdot 1( \pm 7 \cdot 6) \\
12(0-45) \\
26(0-90) \\
50(12-111) \\
45(1-108) \\
121(12-198)\end{array}$ & $\begin{array}{r}<0.001 \\
<0.001 \\
0.031 \\
0.018 \\
<0.001 \\
0.016 \\
<0.001\end{array}$ \\
\hline
\end{tabular}

(FITC) conjugated rabbit anti-mouse IgG (Dako, Denmark).

Samples were analysed as a batch. Cryopreserved tissue blocks were thawed rapidly and disaggregated mechanically, as described before. ${ }^{11} 1516$ The resulting cell suspension was filtered through a $35 \mu \mathrm{m}$ nylon mesh and divided into seven samples containing about $2 \cdot 5-510^{5}$ cells each, which were spun down. A cytospin preparation was made from the first sample, which was used as a cytological control. Only tumour samples that contained more than $50 \%$ of tumour cells were included for further analysis; this resulted in the exclusion of six of the original 86 patients. The five other aliquots were incubated for one hour with the primary antibody raised against EGFR $(50 \mu \mathrm{g} / \mathrm{ml}), c-e r b \mathrm{~B}-2$ $(1 / 250), c-m y c(1 / 20)$, pan-ras $(20 \mu \mathrm{g} / \mathrm{ml})$ and IGF-1 $(20 \mu \mathrm{l} / \mathrm{ml})$, respectively. ${ }^{16}$ The pellet of the seventh aliquot was resuspended in phosphate buffered saline and served as a background fluorescence control. ${ }^{15}$ The optimal staining technique was identified by performing a checkerboard titration of the primary and secondary antibody, optimising the incubation times and volumes and the number of washes. ${ }^{17}$ Labelling the primary antibody with FITC conjugated rabbit anti-mouse IgG and the staining the DNA was performed, as described before. ${ }^{16}$

The cells were analysed simultaneously for DNA and oncoprotein in the Cambridge MRC custom-built dual laser flow cytometer. Excitation, optical filtration, calibration, setup of the flow cytometer, data collection, data processing and data analysis have been given in detail elsewhere. ${ }^{8} 1617$

Cross-blocking assays were carried out using the NEU3 peptide used as the immunogen. Cultured cells known to express high oncoprotein concentrations were used as positive controls: A431 cells (EGFR), SKBRIII (c-erbB-2), NIH3T3 EC816 (Ha-ras), and COLO320 HSR $(c-m y c)$. Cultured cells and tumour samples incubated with monoclonal antibodies against lymphocyte markers (B1, T015, T05 all Dako Ltd, Denmark) gave no substantial signal above background for the gated cells.

\section{Results}

Oncoprotein and receptor expression in normal and carcinomatous ovary is shown in table 2. The median level of expression of all measured oncoproteins was significantly higher in the ovarian cancers. When oncoprotein and receptor concentrations in normal and neoplastic tissue sampled in 1982-1985 were compared with the samples obtained during the period 1986-1989, no significant differences were found. This suggests that there was no major time dependent deterioration of the measured proteins during storage of the biopsy specimens at $-70^{\circ} \mathrm{C}$.

Overexpression (defined as protein concentrations exceeding the 97th centile of the oncoprotein expression in the normal ovary) of $c$-erbB-2, $c$-ras, $c-m y c$, EGFR and ILGFR I 
Table 3 Tumour aneuploidy, $S$ phase fraction, and oncoprotein expression in samples obtained at initial presentation of primary carcinoma of the ovary and in patients with recurrent or progressive ovarian carcinoma after chemotherapy

\begin{tabular}{lccc}
\hline & $\begin{array}{l}\text { Initial } \\
\text { carcinoma } \\
(n=40)\end{array}$ & $\begin{array}{l}\text { Recurrent } \\
\text { carcinoma } \\
(n=40)\end{array}$ & p value \\
\hline Tumour aneuploidy & $24 / 40$ & $23 / 40$ & $\mathrm{NS}$ \\
SPF $^{\star}$ & $18 \cdot 4(7 \cdot 6)$ & $17 \cdot 6(6 \cdot 9)$ & $\mathrm{NS}$ \\
EGFR expression $\dagger$ & $3(0-36)$ & $23(5-48)$ & $0 \cdot 020$ \\
EGFR overexpression $\neq$ & $3 / 40$ & $7 / 40$ & $\mathrm{NS}$ \\
ILGFRI expression $\dagger$ & $7(0-45)$ & $69(6-106)$ & $0 \cdot 001$ \\
ILGFRI overexpression $\ddagger$ & $2 / 40$ & $7 / 40$ & $\mathrm{NS}$ \\
$c$-erbB2 expression $\dagger$ & $35(0-55)$ & $91(31-177)$ & $<0 \cdot 001$ \\
$c$-erbB-2 overexpression $\ddagger$ & $4 / 40$ & $15 / 40$ & $<0 \cdot 005$ \\
$c$-ras expression $\dagger$ & $19(0-76)$ & $61(12-147)$ & $0 \cdot 014$ \\
$c$-ras overexpression $\ddagger$ & $5 / 40$ & $11 / 40$ & $\mathrm{NS}$ \\
$c-m y c$ expression $\dagger$ & $95(0-189)$ & $130(73-199)$ & $0 \cdot 100$ \\
$c$-myc overexpression $\ddagger$ & $12 / 40$ & $16 / 40$ & $\mathrm{NS}$ \\
\hline
\end{tabular}

* Mean (SD), Student's $t$ test

† Median (lower-upper quartile), Mann-Whitney U test

$\ddagger$ Number of cases/total, $\chi^{2}$ test

NS $=$ not significant

Table 4 Oncoprotein overexpression in poor and good responders

\begin{tabular}{llcl}
\hline & \multicolumn{2}{l}{ Survival } & \\
\cline { 2 - 3 } & $\leqslant 30$ months & $>30$ months & p value* \\
\hline EGFR & $10 / 67(15)$ & $0 / 13(0)$ & NS \\
ILGFR 1 & $8 / 67(12)$ & $1 / 13(8)$ & NS \\
$c$-erbB-2 & $17 / 67(25)$ & $2 / 13(15)$ & NS \\
$\begin{array}{l}c-\text { myc } \\
\text { Normal expression of }\end{array}$ & $16 / 67(24)$ & $0 / 13(0)$ & NS \\
$\quad$ all oncoproteins & $26 / 67(39)$ & $2 / 13(15)$ & $<0.04$ \\
$\begin{array}{l}\text { Overexpression of two } \\
\quad \text { or more oncoproteins }\end{array}$ & $30 / 67(45)$ & $10 / 13(77)$ & $\mathrm{NS}$ \\
\hline
\end{tabular}

$\star \chi^{2}$ test

t number of cases/total (percentage)

Patients with a survival of $>30$ months were defined as good responders and patients with a survival of $\leqslant 30$ months as poor responders.

NS $=$ not significant

Table 5 Actuarial survival after surgery: multivariate analysis (Cox regression)

\begin{tabular}{lllll}
\hline Prognostic factor & $p$ value & Coefficient & $\begin{array}{l}\text { Standard } \\
\text { error }\end{array}$ & $\begin{array}{l}\text { Hazard } \\
\text { ratio }\end{array}$ \\
\hline Residual tumour & $<0.001$ & -1.838 & $(0.541)$ & 0.1591 \\
FIGO stage & 0.002 & 1.320 & $(0.420)$ & 3.745 \\
EGFR overexpression & 0.030 & 1.769 & $(0.816)$ & 5.864 \\
Previous chemotherapy & 0.034 & 1.111 & $(0.532)$ & 3.037 \\
\hline
\end{tabular}

was found in, respectively, 19 of $80(24 \%), 16$ of $80(20 \%), 28$ of $80(35 \%), 10$ of $80(12 \%)$ and nine of $80(11 \%)$ of ovarian carcinomas (table 3). There was no correlation between the degree of expression and stage, histology, grade or DNA ploidy of the tumour. S phase fraction was correlated with tumour ploidy $(\mathrm{p}<0.001)$ and EGFR expression $(\mathrm{p}<0.02)$. No correlation could be found among the expression of any of the studied oncoproteins.

Expression of EGFR, ILGFR1, c-erbB-2 and $c$-ras oncoproteins in tumours of patients with recurrent or persistent disease after chemotherapy was significantly higher than in tumours of patients at initial presentation (table 4). In five cases tissue was available for evaluation before and after platinum based chemotherapy. Two of these patients had a similar pattern of oncoprotein expression in tumour retrieved at initial presentation and at second look laparotomy. The other three patients had normal pretreatment tumour oncoprotein concentrations, but overexpression of one or more oncoproteins was found in the persistent tumours.

Oncoprotein expression in relation to actuarial overall survival is given in the figure. Life table analysis (log rank analysis) showed there was a tendency for patients with primary or recurrent tumours overexpressing EGFR ( $p<$ $0.13)$ and $c$-ras $(p<0.17)$ to have a worse prognosis than patients with normal expression of these oncoproteins. Patients with DNA diploid tumours survived significantly longer than patients with DNA aneuploid tumours ( $p<0.013)$. Normal expression of all of the oncoproteins studied was more likely in patients who survived more than 30 months than in those who survived 30 months or less (table 4).

Survival after surgery was calculated using a Cox proportional hazard analysis to determine which variables had an independent prognostic influence and to evaluate their prognostic effect. Initial FIGO stage, tumour histology, tumour grade, residual tumour after surgery, previous platinum based chemotherapy, age, DNA ploidy, $S$ phase fraction, and the expression of EGFR, c-erbB2, ILGFR1, $c-m y c$ and c-ras proteins were analysed. Multivariate analysis revealed that residual tumour, FIGO stage, EGFR overexpression and previous chemotherapy were the only independent variables predicting survival time (table 5).

\section{Discussion}

Several reports have shown that EGFR, ILGFR1, c-myc, c-ras and c-erbB-2 oncoproteins can be detected in the normal ovary by immunohistochemistry, radioimmunoassay, or blotting techniques. ${ }^{781618}$ By measuring messenger RNA, Slamon et al demonstrated an increased expression of the $c-f o s, c-m y c$, $\mathrm{Ha}-$ ras and $\mathrm{Ki}$-ras oncogenes in ovarian carcinomas compared with normal tissues. ${ }^{19}$ Press et al demonstrated that c-erbB-2 expression concentrations in normal tissues were similar to those found in non-amplified, non-overexpressed breast cancers, and breast cancer cell lines. ${ }^{20}$ Median oncoprotein concentrations in the neoplastic samples were significantly higher than in the normal ovaries in the present investigation, though there was a considerable overlap between both groups. These findings support the idea that these oncoproteins have a role in growth control and differentiation of the normal ovary.

In agreement with other investigators, overexpression of one or more of the studied oncogene products could be detected in only a minority of the ovarian cancers. ${ }^{21-24}$ Just over half of the tumours we studied had normal expression of ILGFR1, EGFR, c-erbB-2, c-ras and $c-m y c$ oncoproteins, which means that overexpression of one or more of these oncoproteins seems not to be the common molecular biological event leading to ovarian cancer. Alternatively, a small subset of malignant neoplasms might use this type of abnormal growth control. The molecular biological heterogeneity of epithelial ovarian cancer is illustrated in the present study.

It has been proposed that the hallmarks of tumour progression can probably be attributed to changes in the genes that regulate these functions, allowing sublines of the origi- 
Relation between oncoprotein overexpression and actuarial survival for 80 patients with epithelial carcinoma of the ovary. The number of patients at risk of death at $0,10,20$, $30,40,50$ and 60 months, respectively, is shown.
A

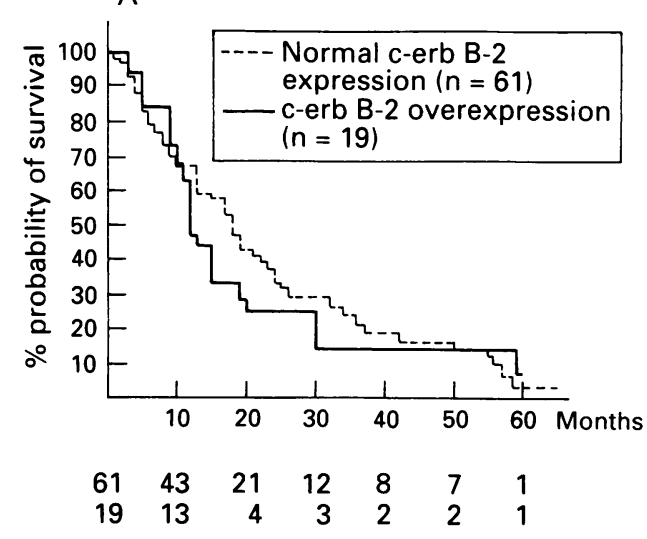

C

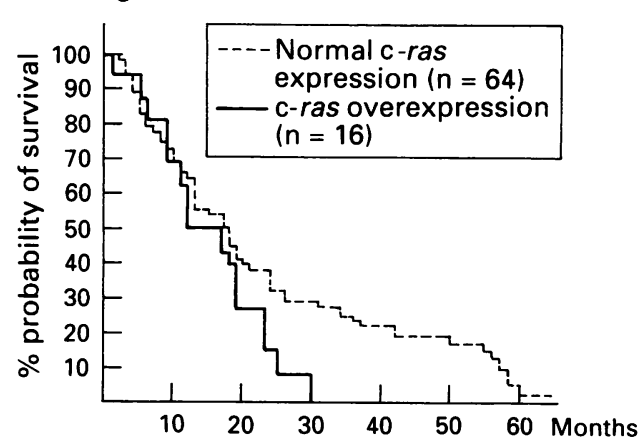

$\begin{array}{rrrrrrr}64 & 42 & 21 & 14 & 10 & 9 & 2 \\ 16 & 14 & 4 & 1 & 0 & 0 & 0\end{array}$

E

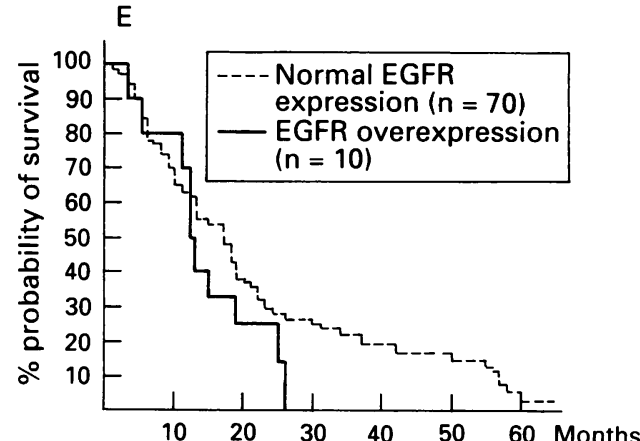

$\begin{array}{rrrrrrr}70 & 48 & 23 & 15 & 10 & 9 & 2 \\ 10 & 8 & 2 & 0 & 0 & 0 & 0\end{array}$

G

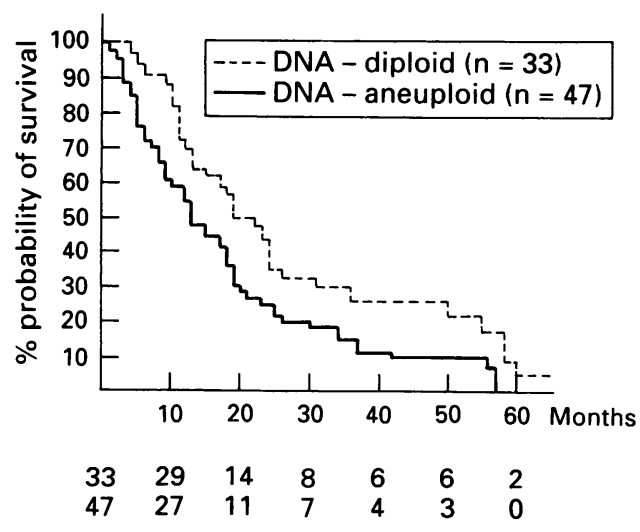

nal neoplastic clone to emerge as predominant. ${ }^{25}$ The present study shows for the first time that there are higher levels of oncoprotein expression in progressive or recurrent tumours than in similar tumours at initial presentation. There also was a significantly

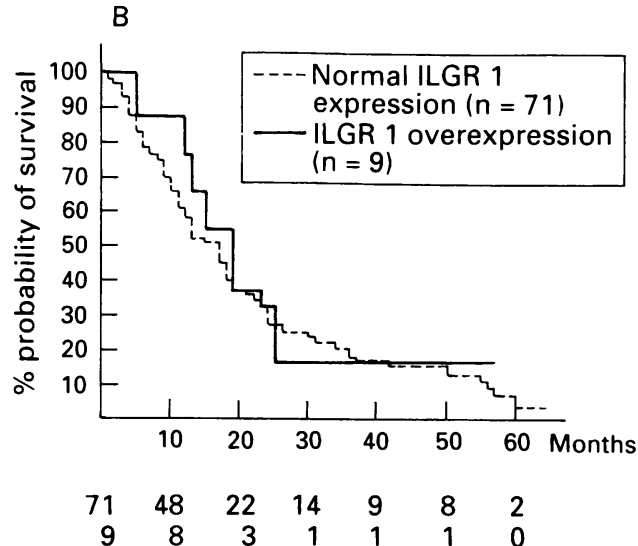

D
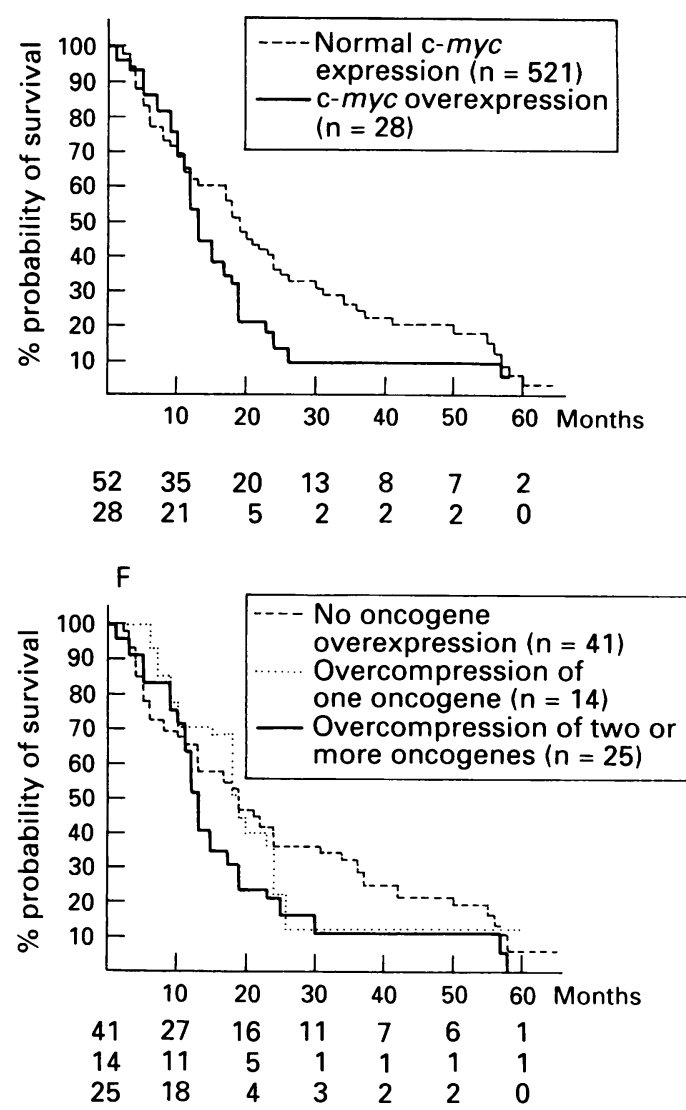

higher incidence of $c$-erbB-2 overexpression in the former group and a similar trend for the other oncoproteins.

Further prospective studies are needed to determine whether these alterations in oncoprotein or receptor expression were already present in the tumour before treatment or were the result of clonal adaptation under chemotherapy. Our observations in patients in whom oncogene expression was measured before and after treatment suggests that in some tumours clonal evolution may be responsible.

Berchuck et al and Kacinski et al found that advanced ovarian tumours with high $c$-erbB-2 expression were significantly less likely to have a complete response to primary therapy. ${ }^{21} 26$ This trend was also described in patients with neuroblastoma and leukaemia. ${ }^{27-29}$ Preisler et al found that high levels of $c-m y c$ expression in patients with acute non-lymphocytic leukaemia are associated with a high probabil- 
ity that the patients will not respond to remission induction treatment or will have only short remissions. ${ }^{30} 31$ The ras oncogene may have a role in tumour progression and also influence the development of radiation resistance..$^{32} 33$ In vitro and in vivo experiments indicate that exposure of $c-m y c$ and $c$-ras expressing cells to hypomethylating agents can lead to tumour progression. ${ }^{34}$ This indicates that pre-existing alterations in oncogene expression may facilitate the malignant evolution in some tumours treated with certain types of chemotherapy.

It was found in the present study that EGFR overexpression is an independent prognostic factor in patients with epithelial ovarian cancer. Studies by Bauknecht et al and Berchuck et al have suggested that high levels of EGFR expression are a marker of bad prognosis in ovarian cancer patients. ${ }^{323} 24$ Although our data and a recently published study by Henzen-Logmans et al show that EGFR overexpression occurs only in about $12 \%$ of ovarian carcinomas, the present findings suggest that it is an important molecular biological event in the progression of ovarian cancer. ${ }^{35}$ The investigation by HenzenLogmans et al indicates that EGFR overexpression is rarely due to amplification of the EGFR gene and that altered transcription seems important. ${ }^{35}$

Both c-erbB-2 amplification and overexpression are associated with decreased survival in ovarian carcinoma according to some authors. ${ }^{1822}$ Haldane et al, on the other hand, could not confirm that there was an adverse prognostic effect of $c$-erbB-2 expression in a series of 104 immunostained epithelial ovarian malignancies. ${ }^{36}$ Kacinski et al could not identify a correlation between the intensity of $c$-erbB-2 in situ hybridisation staining and either relapse free or overall survival in 72 patients with stage I to IV ovarian carcinoma. ${ }^{26}$ This agrees with the findings of this study.

Amplification and overexpression of the $\mathrm{Ki}$ ras oncogene has been reported in only a small proportion of ovarian cancers. ${ }^{37-39}$ In immunohistochemical studies of patients with advanced ovarian cancer, Rodenburg $e t$ al and Yaginuma et al found no correlation between staining intensity of the ras gene product $\mathrm{p} 21$ and the histological type, grade, the ploidy class, and the clinical outcome. ${ }^{7}{ }^{40}$ The relevance of ras gene product p21 to the diagnosis and prognosis of gynaecological malignancies remains to be determined.

Polacarz et al detected strong c-myc immunostaining of the nucleus and entire cytoplasm in all 22 cases of mucinous cystadenocarcinoma of the ovary. ${ }^{41}$ Although only small numbers of cases have been studied, $c$ $m y c$ amplification and overexpression seem to be a common finding (25-50\%) in advanced stage ovarian cancer. ${ }^{42} 43$ In an immunohistochemical study Sasano et al could find no significant correlation in cases of ovarian cancer between intracellular localisation patterns of the $c-m y c$ oncoprotein and histological and nuclear grades or mitotic activity. ${ }^{43}$
We thank Dr Bill Gullick (London) for providing the R1 monoclonal antibody. Dr P van Dam is supported by a Belgisch Werk tegen Kanker, a British Council and a St Bartholomew's Cancer Research Campaign grant.

1 Weinstein IB. The origins of human cancer: molecular mechanisms of carcinogenesis and their implication for cancer prevention and treatment. 27th GHA Clowes memorial award lecture, Cancer Res 1989;48:4135-43.

2 Gullick WJ, Marsden J, Whittle N, Ward B, Bobrow L, Waterfield MD. Expression of epidermal growth factor receptors on human cervical, ovarian and vulval carcinoreceptors on human cervical, ovar

3 Berchuck A, Rodriguez GC, Kamek A, Dodge RK, Soper JT, Clarke-Pearson DL, et al. Epidermal growth factor receptor expression in normal ovarian epithelium and ovarian cancer. Am f Obstet Gynecol 1991;164:669-74.

4 Vogelstein B. A deadly inheritance. Nature 1990;348: $681-2$.

5 Gullick WJ, Berger MS, Bennett PL, Rothbard JB, Waterfield MD. Expression of the c-erbB-2 protein in normal and transformed cell. Int $\mathcal{f}$ Cancer 1987; 40:246-54.

6 Gullick WJ, Waterfield MD. Epidermal growth factor and its receptor. In: Strasberg AD, ed., Molecular biology of receptors, Chichester: Ellis Horwood, 1987:15-35.

7 Rodenburg CJ, Koelma IA, Nap M, Fleuren GJ. Immunohistochemical detection of the ras oncogene product p21 in advanced ovarian cancer. Arch Pathol Lab Med 1988;112:151-4.

8 Watson JV, Curling OM, Munn CF, Hudson CN. Oncogene expression in ovarian cancer: a pilot study of c-myc oncoprotein in serous papillary ovarian cancer. Gynecol Oncol 1987;28:137-50.

9 Shepherd JH. Revised FIGO staging for gynaecological cancer. Br $\dot{f}$ Obstet Gynaecol 1989;96:889-92.

10 Scully RE. Tumors of the ovary and maldeveloped gonads. In: Scully RE, ed. Atlas of tumor pathology. Series 2. Fascicle 16. Washington, DC: Armed Forces Institute of Fascicle 16. Wash

11 van Dam PA, Lowe DG, Shepherd JH, Vergote IB, Watson JV. Multiparameter flow cytometric quantitation of membrane proteins in long-term cryopreserved solid tumours. Lancet 1990;ii:689.

12 Price KM, Cuthbertson AS, Varndell IM, Sheppard PW. The production and characterisation of monoclonal antibodies to myc, c-erbB-2 and EGF-receptor. Devel Biol Standard 1989;71:23-31.

13 Waterfield MD, Mayes EL, Stroobant P, Bennett PL, Young S, Goodfellow PN, et al. A monoclonal antibody Young S, Goodfellow PN, et al. A monoclonal antibody to the human epidermal

14 Evan GI, Lewis GK, Ramsay G, Bishop JM. Isolation of monoclonal antibodies specific for human and mouse proto-oncogene products. Mol Cell Biol 1985;5:3610-6.

15 van Dam PA, Watson JV, Lowe DG, Chard T, Shepherd $\mathrm{JH}$. Comparative evaluation of fresh, fixed and cryopreserved solid tumor cells for reliable flow cytometry of DNA and tumor associated antigen. Cytometry 1992; 13:722-9.

16 van Dam PA, Lowe DG, Watson JV, James $M$, Chard T, Hudson CN, et al. Multiparameter flow cytometric Hudson CN, et al. Multiparameter flow cytometric quantitation of EGF receptor and c-erbB-2 oncoprotein
in normal and neoplastic tissues of the female genital in normal and neoplastic tissues of

17 van Dam PA, Watson JV, Lowe DG, Cox H, Curling OM, Shepherd JH. Tissue preparation for simultaneous flow cytometric quantitation of tumour associated antigens and DNA in solid tumours. F Clin Pathol 1990;43: 833-9.

18 Owens OJ, Leake RE. Epidermal growth factor receptor in normal ovaries and benign ovarian tumours. Eur $\mathcal{F}$ Obstet Gynecol Reprod Biol 1992;47:229-33.

19 Slamon DJ, DeKernion JB, Verma IM, Cline MJ. Expression of cellular oncogenes in human malignanExpression of cellular oncogen
cies. Science 1984;224:256-62.

20 Press MF, Cordon-Cardo C, Slamon DJ. Expression of the HER-2/neu proto-oncogene in normal adult and fetal tissues. Oncogene 1990;5:953-62.

21 Berchuck A, Kamel A, Whitaker R, Bast RC. Overexpression of HER-2/neu is associated with poor survival in advanced epithelial ovarian cancer. Cancer Res 1990;50:4087-91.

22 Slamon DJ, Godolphin W, Jones LA, Holt JA, Wong SG, Keith DE, et al. Studies of the HER-2/neu protooncogene in human breast and ovarian cancer. Science gene in human $244: 707-12$.

23 Bauknecht $T$, Janz I, Kohler M, Pfleiderer A. Human ovarian carcinomas: correlation of malignancy and surovarian carcinomas: correlation of malignancy and sur-
vival with the expression of epidermal growth factor vival with the expression of epidermal growth factor receptors and EGF-like fact

24 Bauknecht T, Birmelin, Kommoss F. Clinical significance of oncogenes and growth factors in ovarian carcinomas. $\mathcal{F}$ Steroid Biochem Mol Biol 1990;37:855-62.

25 Tsujino T, Yoshida K, Nakayama $H$, Ito H, Shimosato T Tahara E. Alterations of oncogenes in metastatic tumours of human gastric carcinomas. $\mathrm{Br} \mathcal{F}$ Cancer 1990;62:226-30.

26 Kacinski BM, Mayer AG, King BL, Carter D, Chambers SK. Neu protein overexpression in benign, borderline and malignant ovarian neoplasms. Gynecol Oncol 1992;44:245-53.

27 Combaret V, Wang Q, Favrot MC, Thiesse P, Philip I 
Bouffet $\mathrm{E}$, et al. Clinical value of $\mathrm{N}$-myc amplification in 52 patients with neuroblastoma included in recent therapeutic protocols. Eur $\mathcal{F}$ Cancer Clin Oncol 1989;25: peutic proto $1607-12$.

28 Kaida S, Fujikawa T, Endou S, Inaba S, Nagayama Y, Sakato $\mathrm{H}$, et al. The changes of mRNAs of both c-myc and MDR1 in CML-bc tumor cells during the clinical course: a case report (abstract). Rinsho Ketsueki 1990; 30:697-701.

29 Ross DW, Dent G. Juvenile chronic myeloid leukemia oncogene characterization. Pediatr Pathol 1989;9: 669-78.

30 Preisler HD, Raza A, Larson R, LeBeau M, Browman G Goldberg J, et al. Protooncogene expression and the clinical characteristics of acute non-lymphocytic leukemia: a Leukemia Intergroup pilot study. Blood 1989;73: 255-62.

31 Bos JL. Ras oncogenes in human cancer: a review. Cancer Res 1989;49:4682-9.

32 Muschel RJ, McKenna WG. Oncogenes and tumor progression. Anticancer Res 1989;9:1395-406.

33 McKenna WG, Weiss MC, Endlich B, Ling CC Bakanauskas VJ, Kelsten ML, et al. Synergistic effect of vmyc oncogene with $\mathrm{H}$-ras on radioresistance. Cancer Res 1990;50:97-102.

34 Rimoldi D, Srikantan V, Wilson VL, Bassin RH, Samid D. Increased sensitivity of non-tumorigenic fibroblasts expressing ras or myc oncogenes to malignant transformation induced by 5-aza-2'-deoxycytidine. Cancer Res mation induced

35 Henzen-Longmans SC, Beins EM, Klyn JG, van den Burg $\mathrm{ME}$, Foekens JA. Epidermal growth factor receptor in ovarian tumours: correlation of immunohistochemistry with ligand binding assay. $\mathrm{Br} F$ Cancer 1992;66: 1015-21.

36 Haldane JS, Hird V, Hughes CM, Gullick WJ. C-erbB-2 oncogene expression in ovarian cancer. $f$ Patho 1990;162:231-7.

37 Masuda H, Battifora $\mathrm{H}$, Yokota J, Meltzer S, Cline MJ Specificity of proto-oncogene amplification in human malignant diseases. Mol Biol Med 1987;4:213-27.

38 Van 't Veer LJ, Hermens R, Van den Berg-Bakker LA Cheng NC, Fleuren GJ, Bos JL, et al. Ras oncogene activation in human ovarian carcinoma. Oncogene 1988; 2:157-65

39 Fukumoto $M$, Estensen RD, Sha L, Oakle GJ, Twiggs LB Adcock LL, et al. Association of $\mathrm{Ki}$-ras with amplified DNA sequences, detected in human ovarian carcinomas by a modified in-gel renaturation assay. Cancer Res by a modified

40 Yaginuma Y, Yamashita K, Kuzumaki N, Fujita $M$ Shimizu T. Ras oncogene product p21 expression and prognosis of human ovarian tumours. Gynecol Oncol 1992;46:45-50.

41 Polacarz SV, Hey NA, Stephenson TJ, Hill AS. C-myc oncogene product $\mathrm{p} 62 \mathrm{c}-\mathrm{myc}$ in ovarian mucinous neoplasms: immunohistochemical study correlated with malignancy. F Clin Pathol 1989;42:148-52.

42 Kohler M, Janz I, Wintzer HO, Wagner E, Bauknecht T. The expression of EGF receptors, EGF-like factors and cmyc in ovarian and cervical carcinomas and their potential clinical significance. Anticancer Res 1989;9:1537-48.

43 Sasano H, Garrett CT, Wilkinson DS, Silverberg S Comerford J, Hyde J. Protooncogene amplification and tumor ploidy in human ovarian neoplasms. Hum Patho 1990;21:382-91. 